\title{
Spatial dispersal of Metarhizium anisopliae and Beauveria bassiana in soybean fields
}

\author{
Heverly das Merces Guinossi ${ }^{1}$, Flávio Moscardi ${ }^{3}$, Maria Cristina Neves de Oliveira² \& Daniel Ricardo \\ Sosa-Gómez ${ }^{2}$
}

'Departamento de Zoologia, Universidade Federal do Paraná, 81531-980, Curitiba, PR, Brazil; ${ }^{2}$ Embrapa Soja, Cx. Postal 231, 86001-970, Londrina, PR, Brazil; ${ }^{3}$ Centro de Ciências Agrárias, Universidade Estadual de Londrina, Cx. Postal 6001, 86051-990, Londrina, PR, Brazil

Author for correspondence: Daniel Ricardo Sosa-Gómez, e-mail: drsg@cnpso.embrapa.br

\begin{abstract}
The dispersal and persistence of Beauveria bassiana and Metarhizium anisopliae following application in soybean fields as kaolin dust and sprays of soybean oil formulations were investigated. Fungal dispersion was evaluated from a centrally-treated area by sampling leaflets on eight transects at 20-m intervals in concentric rings up to $100 \mathrm{~m}$ from the central area. Density of colony-forming units (CFU) per unit leaf area was determined by washing the soybean leaflets in water containing Tween 80, and plating the aqueous suspensions on an oatmeal-dodine semi-selective agar medium. Spatial dispersal of B. bassiana in soybean field was significantly higher when conidia were applied as an oil formulation compared with a kaolin dust formulation. No significant differences were observed in M. anisopliae CFU number between sprayed or dusted plots. Oil-based formulations favor the dispersal of B. bassiana in soybean crops, but not the dispersal of M. anisopliae. Kaolin-based formulations are not suitable for B. bassiana or M. anisopliae dispersal.
\end{abstract}

Key words: entomopathogens, epizootiology, fungi, insect, persistence.

\section{RESUMO}

Dispersão espacial de Metarhizium anisopliae e Beauveria bassiana em campos de soja

A dispersão e a persistência de Beauveria bassiana e Metarhizium anisopliae mediante aplicações por polvilhamento e pulverização em óleo de soja em campos de soja foram estudados. A dispersão fúngica foi avaliada a partir de uma área central mediante a amostragem de folíolos sobre oito transectos dispostos em anéis concêntricos em intervalos de $20 \mathrm{~m}$ até $100 \mathrm{~m}$ da área central. A densidade de unidades formadoras de colônias (UFC) por unidade de área foliar foi determinada mediante lavado dos folíolos de soja em água contendo Tween 80 e plaqueamento das suspensões em água em meio seletivo dodine-aveia-agar. A dispersão espacial de B. bassiana no campo de soja foi significativamente maior quando os conídios foram aplicados com óleo em comparação com a aplicação por polvilhamento. Não foram observadas diferenças significativas no número de UFC de $M$. anisopliae entre as parcelas pulverizadas ou polvilhadas. As aplicações em óleo favoreceram a dispersão de $B$. bassiana na cultura da soja, mas não a de $M$. anisopliae. As misturas em caulim não são apropriadas para a dispersão de B. bassiana ou de M. anisopliae.

Palavras-chave: entomopatógenos, epizootiologia, fungos, persistência, insetos.

\section{INTRODUCTION}

In Brazilian soybean fields, the entomopathogenic fungus Beauveria bassiana acts as a natural control agent for Aracanthus mourei (Col.: Curculionidae), Cerotoma sp., Diabrotica speciosa, and Colaspis sp.(Col.: Chrysomelidae), and interestingly, as an endophyte, this species also provides a protective effect against plant pathogens (Ownley et al., 2008). In addition, Metarhizium anisopliae plays an important role in controlling soil-inhabiting insects such as Scarabaeidae (Sosa-Gómez \& Moscardi, 1994). The potential of entomopathogens as microbial control agents has been studied (Johnson \& Goettel, 1993), but their dispersion patterns in crops following artificial application has received little attention. More emphasis has been placed on the dissemination of entomopathogens in natural epizootics (Fuxa, 1984). The dispersal of some naturally occurring pathogens, such as Nomuraea rileyi and Entomophthora maimaiga, has been reported (Fuxa, 1984; Hajek et al., 1996). Improved knowledge of the spread of fungi following artificial applications would contribute to the understanding of factors regulating disease epidemics in field populations of insects and provide a basis, in a broad sense, for improving the technology for treating crops with pest and plant disease control agents.

Interest in oil-based formulations of entomopathogenic fungi has increased in recent years due to improved persistence (Inglis et al., 1995a), storage (Alves et al., 2002), protection from imbibitional damage (Faria et al., 2009), and increased mortality of target insects (Bateman et al., 1993). Little is known about the persistence and survival of the fungal inocula following application in crops 
or how much secondary dispersal occurs after application. Our objective was to monitor the spatial dispersal of $M$. anisopliae and B. bassiana in soybean fields following application of conidia of the pathogens in oil-based and kaolin-based formulations.

\section{MATERIALS AND METHODS}

\section{Fungal material}

M. anisopliae sensu lato (CNPSo-Ma12 = ARSEF 5161) was isolated from soil and B. bassiana (CNPSoBb13) from Diabrotica speciosa (Col.: Chrysomelidae). The identity of both fungal species was confirmed by microscopic examination. Inoculum of the fungi was produced on rice grains according to Alves \& Pereira (1989). After 15 days of growth, the conidia were separated from the rice medium using a standard soil sieve number 20 (50 mesh), and stored, unformulated, at $-15^{\circ} \mathrm{C}$ for 10 days, before further use. Viability was determined by plating conidial suspensions on potato dextrose agar amended with $0.05 \%(\mathrm{w} / \mathrm{v})$ streptomycin sulphate. After $24 \mathrm{~h}$ of incubation at $26 \pm 1{ }^{\circ} \mathrm{C}$ in the dark, conidia were stained with lactophenol and cotton blue (SigmaAldrich, São Paulo, SP, Brazil), and 100 conidia from each of the four replicate cultures were examined for germ tube formation. Conidial concentrations for field tests were estimated from aliquots with a hemocytometer, and dry conidia were mixed with kaolin (22 to $23 \mu \mathrm{m}$ particle size; Mineração Hori, Mogi das Cruzes, SP, Brazil) or suspended in commercially-refined edible soybean oil (Coamo, Campo Mourão, PR, Brazil) as required.

\section{Field assays}

Two 10,000- $\mathrm{m}^{2}$ experimental areas were established with the soybean cultivar BR16. Experimental areas were located $\sim 13 \mathrm{~km}$ due north of Londrina, Paraná State (W $23^{\circ} 11^{\prime} 37.0^{\prime \prime}, \mathrm{S} 51^{\circ} 11^{\prime} 5.0^{\prime \prime}$, Datum WGS84). In the summer, one area was treated with a dust formulation and the other with a soybean oil-conidia formulation, and the same procedure was used in the following soybean growing season. Immediately before application, dry M. anisopliae and B. bassiana conidia were suspended at $2 \%(\mathrm{w} / \mathrm{v})$ in soybean oil or at $10 \%(\mathrm{w} / \mathrm{v})$ in kaolin. A high dosage of 7.8 $\pm 0.6 \times 10^{10}$ viable conidia was applied to a central $10-\mathrm{m}^{2}$ area to facilitate detection in the subsequent days after application. Conidia suspended in soybean oil were applied with a Backpack Sprayer (model X15, Jacto, Pompéia, SP, Brazil) using a hollow cone nozzle $\left(300 \mathrm{~L} \mathrm{ha}^{-1}\right)$. The dry formulation was spread by hand using a plastic dispenser with $0.6-\mathrm{mm}$ diameter holes. At application, plants were $65 \mathrm{~cm}$ high and at the R2 stage (Fehr \& Caviness, 1977). Immediately after application, samples of leaves were taken from each plot as defined by the intersection of concentric circles and transects laid out at 20-m intervals in eight opposing directions, arranged on north, northeast, east, southeast, south, southwest, west, and northwest axes (Figure 1). Samples were taken immediately before and after application and at 2-day intervals up to 11

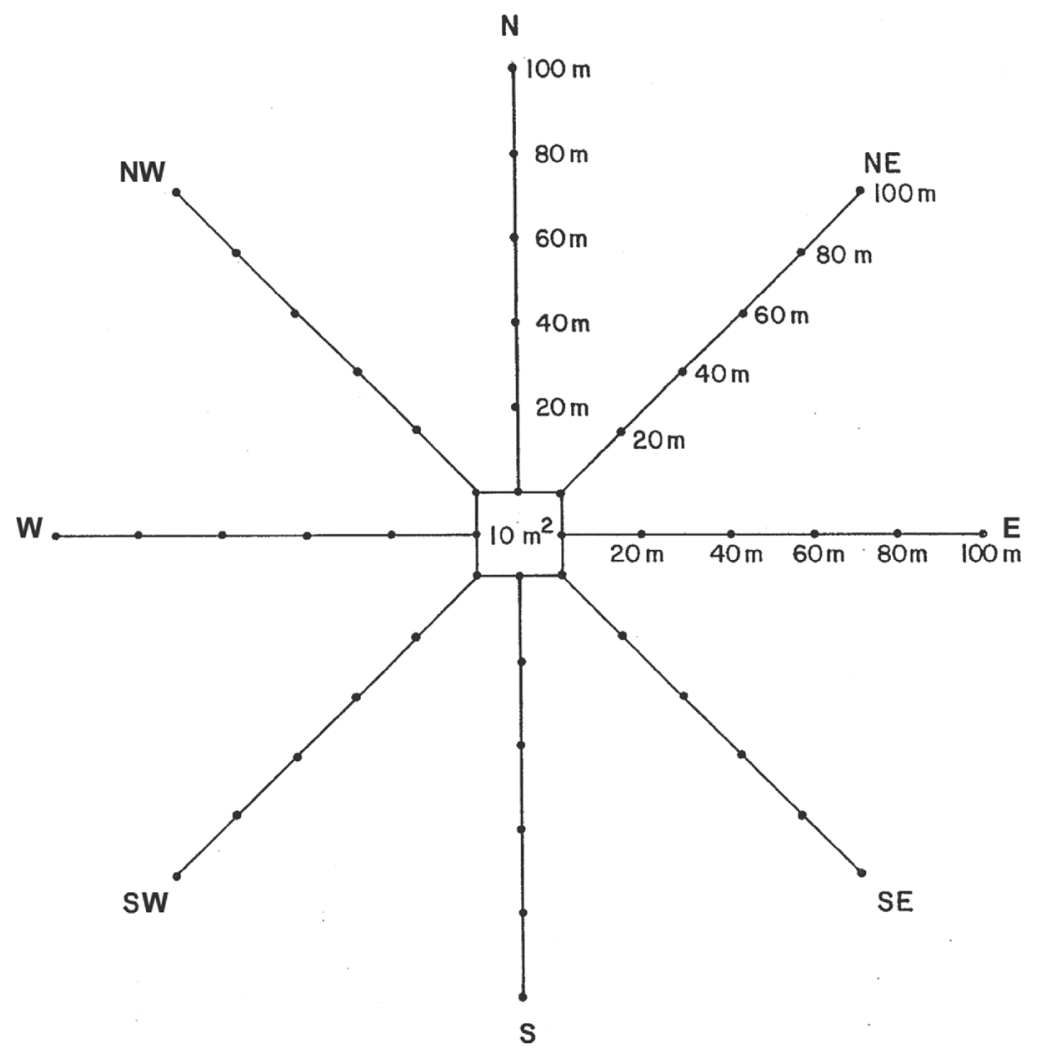

FIGURE 1 - Diagram of sample points used to evaluate dispersion of colony forming units of Beauveria bassiana and Metarhizium anisopliae after application in a central $10-\mathrm{m}^{2}$ square in soybean field plots. 
or 12 days post-treatment. Previous studies had indicated that both fungi persist for 8-12 days in soybean fields (SosaGómez \& Moscardi, 1998). Mature soybean leaflets were sampled, dried with silica gel to preserve the inocula, and stored at $-20^{\circ} \mathrm{C}$ up to 4 months until assessed for colony forming units (CFU) (Hedgecock et al. 1995). At each sampling date, we collected 41 leaflets $\left[1165 \pm 197 \mathrm{~cm}^{2}\right.$ $(\mathrm{n} \pm \mathrm{SEM})]$ from the central plot and from the intersections of the concentric circles and transects (Figure 2). To recover propagules of $M$. anisopliae and B. bassiana, each
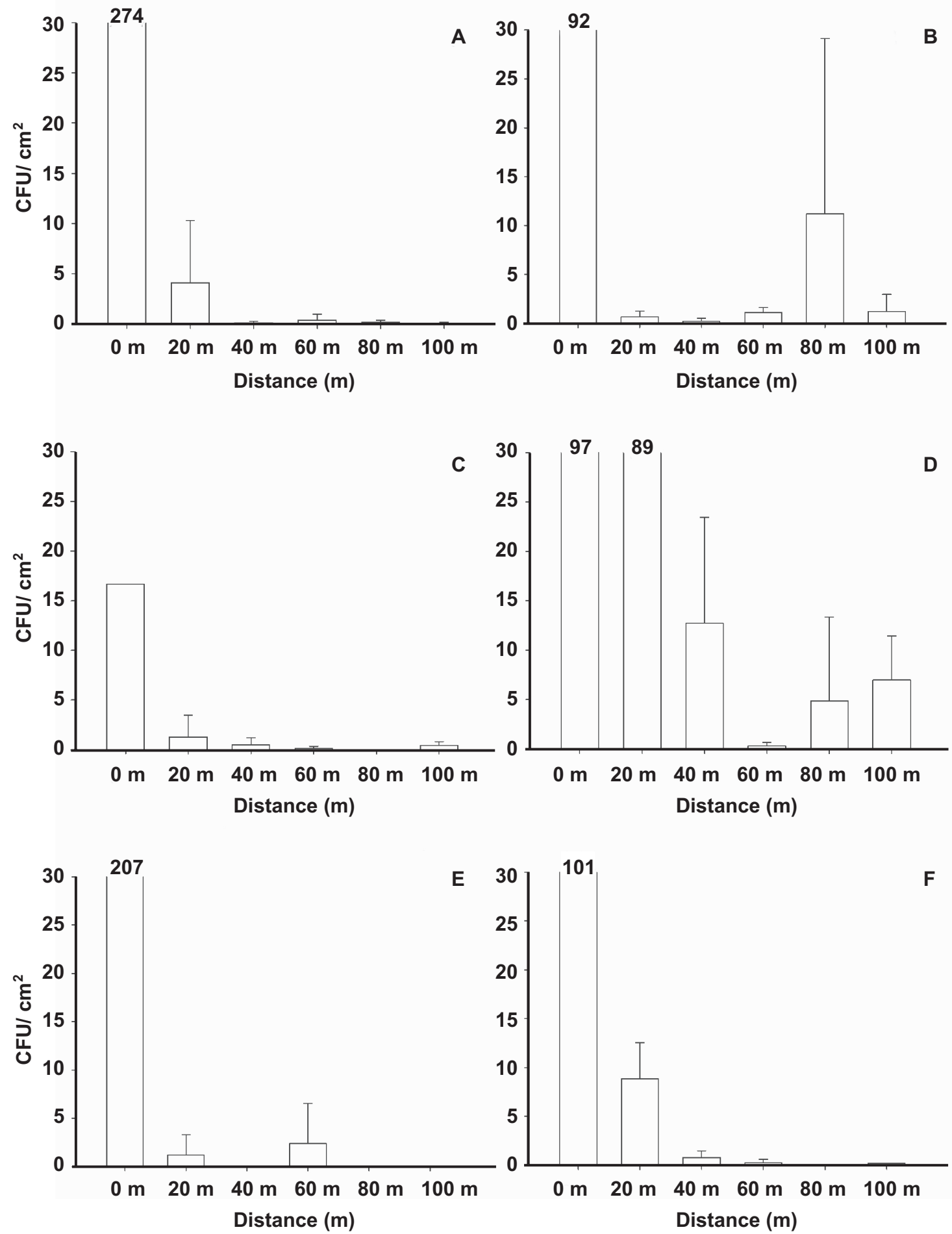

FIGURE 2 - A.D. Dispersion distance of colony-forming units (mean values) on soybean leaflets immediately after application of Beauveria bassiana and E.F. Metarhizium anisopliae; A.C.E. entomopathogenic fungi using kaolin as a carrier or B.D.F. soybean oil A.B. in the first and C-F. second growing seasons of the experiment. Error bars are $95 \%$ confidence intervals. 
leaflet was vigorously vortexed for $1 \mathrm{~min}$ in $10 \mathrm{~mL}$ aqueous solution of $0.01 \%(\mathrm{v} / \mathrm{v})$ Tween 80 , and $0.2 \mathrm{~mL}$ aliquots of the suspension were serially diluted $\left(10^{-1}, 10^{-2}\right.$, and $\left.10^{-3}\right)$ and plated on oatmeal-dodine (Venturol, $650 \mathrm{~g} \mathrm{~kg}^{-1}$, BASF, Germany) agar medium in Petri dishes (Chase et al., 1986). B. bassiana, M. anisopliae and M. robertsii are tolerant to the concentration of dodine used in this selective medium (Rangel et al., 2010). The washed leaflets were dried, and the area of each leaf was estimated with a leaf area meter (Model 3100, Li-Cor, Lincoln, NE, USA). Mean values were calculated after the number of CFU was quantified with a colony counter (Model EC 550A, Phoenix, São Paulo, SP, Brazil). Rain, wind speed, and temperature data were obtained from a weather station located $500 \mathrm{~m}$ from the field study.

\section{Statistical analysis}

The CFU per $\mathrm{cm}^{2}$ of leaflets were analyzed by the non-parametric Mann-Whitney rank sum test with Sigmastat Software (Jandel Scientific, 1994) to determine differences among areas treated with kaolin-based and soybean oil-based formulations. Although the processed samples were numerous, insufficient data were obtained to allow a geostatistical study of surface distribution.

\section{RESULTS}

\section{First growing season}

One hour after application, there was a rain shower of $33.4 \mathrm{~mm} \mathrm{~h}^{-1}$, the total rainfall on this day. Low-intensity showers $(0.1,0.9$, and $1.2 \mathrm{~mm})$ were registered at days 3 , 4 , and 5 , respectively. B. bassiana occurred naturally in the dusted plot, where one CFU was recovered at $40 \mathrm{~m}$ northeast of the central area and one at $100 \mathrm{~m}$ on the east side, but none was found in the sprayed plot. The average CFU densities of $B$. bassiana on the foliage in the $10-\mathrm{m}^{2}$ central area immediately after application of the dust and

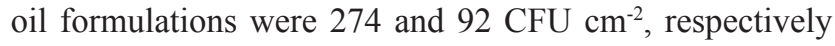
(Figs. 2A, 2B). Approximately $3 \mathrm{~h}$ after treatment, CFU were found at $47.5 \%$ of the sample sites in the plot treated with oil-formulated conidia, up to $100 \mathrm{~m}$ from the treated plot, whereas the area treated with powder formulation had low CFU counts at $20 \%$ of the sample points. Overall mean CFU counts were significantly greater for the oil than for the dust formulation $(\mathrm{T}=1933, P=0.032)$. Mean CFU counts at day 3 after application were significantly higher in the sprayed area (occurring at $37 \%$ of the sample points) compared to the dusted area (no CFU detected at the sample points) $(\mathrm{T}=1983, P=0.009)$. At day 5 , the numbers of CFU in the two areas were not significantly different $(\mathrm{T}=1660.5, P=0.706) ; B$. bassiana was present at seven and five points outside the central square in the dust- and oiltreated areas, respectively, with densities ranging between 1

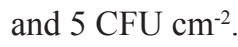

Leaflets collected before fungal application in the dusted and sprayed plots did not contain detectable $M$. anisopliae CFU. M. anisopliae deposits on soybean leaves immediately after application were 5 and $16 \mathrm{CFU} \mathrm{\textrm {cm } ^ { - 2 }}$ in the dusted and sprayed sites, respectively, and fungal dispersion was up to $60 \mathrm{~m}$ for both areas. The numbers of $\mathrm{CFU}$ on soybean leaves dusted with kaolin or sprayed with soybean oil were not significantly different at days 1,3 , 5 , or 7 after application $(\mathrm{T}=1660, P=0.703 ; \mathrm{T}=1638$, $P=0.557 ; \mathrm{T}=1758, P=0.602 ; \mathrm{T}=1701, P=1.000$, respectively). The average number of CFU of $B$. bassiana and $M$. anisopliae in the entire experimental area was less

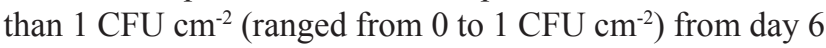
to day 12 after application.

\section{Second growing season}

Estimated densities of naturally-occurring $B$.

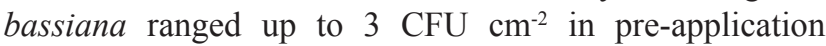
samples. Foliar deposits of B. bassiana from kaolin and oil conidial formulations, respectively, were 17 and $97 \mathrm{CFU}$ $\mathrm{cm}^{-2}$ (Figs. 2C, 2D). In both treatments, the number of CFU increased immediately after treatment, presenting higher density in the area sprayed with the oil formulation than in the area dusted with dry conidia in kaolin, occurring at $90 \%$ and $15 \%$ of the sample points, respectively $(\mathrm{T}=2329$, $P<0.001)$. These CFU counts were higher at 20, 40, 80, and $100 \mathrm{~m}$ from the central oil-treated plot than on the field treated with the dust formulation (Figs. 2C, 2D). After $24 \mathrm{~h}$ and over the following days, no significant differences were observed in the numbers of $B$. bassiana CFU in both areas.

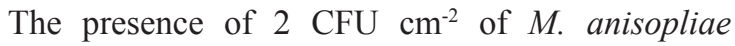
was detected before application at one sample point. As in the first trial, immediately after treatment, there was no significant difference between $\mathrm{CFU} \mathrm{\textrm {cm } ^ { - 2 }}$ in plots that had been treated with $M$. anisopliae conidia in oil or dust $(\mathrm{T}=1911.5, \mathrm{P}=0.051)$. M. anisopliae deposits on soybean leaves immediately after application were 207 and $101 \mathrm{CFU}$ $\mathrm{cm}^{-2}$ in the dusted and sprayed plots, respectively, with fungal dispersion up to $100 \mathrm{~m}$ for oil treatment (Figs. 2E, 2F). $M$. anisopliae colonies were present at $32.5 \%$ and $5 \%$ of sample sites in the oil formulation and dust-treated areas, respectively. CFU counts ranged from 0 to 6 and from 1 to 2 counts in the oil and dust-treated areas, respectively. No significant differences

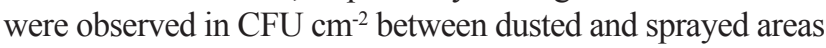
at days $3,7,9$, and 11 after application $\mathrm{T}=1661, P=0.709$; $\mathrm{T}=1682, P=0.859 ; \mathrm{T}=1662, P=0.716 ; \mathrm{T}=1740, P=0.720$, respectively). At day 1 after application, the numbers of CFU remained high only in the central square plot that received the

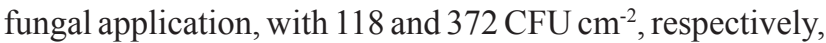
in the plots treated with the oil and dust formulations. In both areas, the highest CFU densities were observed only in the central plot until day 11 after application. There was no reduction in $M$. anisopliae $\mathrm{CFU}$ after day 2, when 9.1 $\mathrm{mm}$ rain fell in $5 \mathrm{~h}$. The density of CFU was lower for $M$. anisopliae than for B. bassiana. The density of $M$. anisopliae

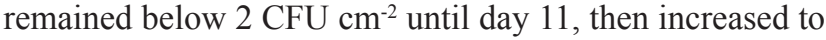

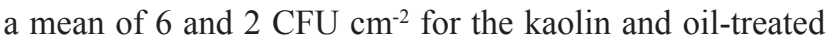
plots, respectively. 


\section{DISCUSSION}

The application of conidia suspended in soybean oil favored the dissemination of B. bassiana. M. anisopliae conidia suspended in oil or in kaolin formulations did not spread as well as $B$. bassiana outside the treated central square during the first 2-3 $\mathrm{h}$ after application. Spread of $B$. bassiana after application was greater than that of $M$. anisopliae. The smaller size of the B. bassiana conidia (2.1$2.6 \mu \mathrm{m})$ compared to $M$. anisopliae $(5.0-7.0 \times 2.0-3.5 \mu \mathrm{m})$ may favor its airborne dispersal and spread. Also, differences of conidial attachment to soybean surfaces could be another possible factor, considering that $M$. anisopliae conidia have a bigger surface compared to B. bassiana.

Numbers of recovered CFU were high for the treated central square areas at days 2 or 3 after application, but low outside these areas. Using a semi-selective dodine-based medium, Sosa-Gómez \& Moscardi (1998) reported that the half-life of M. anisopliae and B. bassiana was between 1.2 and 2.9 days on soybean leaves, and this was confirmed using the same method in the present trials.

Artificial applications of Metarhizium conidia in the present studies increased the inocula level above naturally occurring densities reported by Sosa-Gómez et al. (2001), however, Beauveria increased but was in the range of natural occurrence reported previously. Inglis et al. (1995b) reported that $26.7 \mathrm{~mm} \mathrm{~h}^{-1}$ of rain, less than that observed in this study, could reduce $B$. bassiana conidial populations on leaves. Therefore, the $34.8 \mathrm{~mm}$ of rain $1 \mathrm{~h}$ after application may have affected leaf retention of both fungal species in the first field season.

According to Garcia \& Ignoffo (1977), the minimum wind speed to dislodge conidia of Nomuraea rileyi (another clavicipitaceous fungus with dry airborne conidia) from dead larvae was $2.7 \mathrm{~km} \mathrm{~h}^{-1}$. These findings suggest that the wind speeds registered during the present field studies (6.5 $\mathrm{km} \mathrm{h}^{-1}, 3-9$ on average) were sufficient to disperse conidia of $M$. anisopliae and B. bassiana in the soybean foliage. Our observations during the first three days after application that CFU densities were greater on leaflets from the north and west sectors compared to the other sectors are possibly attributable to prevalence of winds from the east, south, and southeast sides.

Based on the weather station records, the reported dispersal and survival of the entomopathogens in the soybean field plots took place during weather that was generally warm $\left(17-34^{\circ} \mathrm{C}\right)$ and sunny. Cloudiness occurred mainly in association with the rainshowers. Specific effects of microclimatic variables (e.g. temperature, irradiance, water potentials) on populations of the entomopathogens on soybean foliage, however, are not well understood. Conidia remaining on the boundary layer, defined as the transition zone above the leaf surface, are exposed to localized microclimate conditions, which are difficult to evaluate in relation to spore population dynamics (Southwick \& Ferro, 1984; Jaronski, 2010).
The beneficial effects of mineral and vegetable oils on entomopathogenic fungi include a protective effect against ultraviolet light (Moore et al., 1993) and a greater temperature tolerance than that observed for aqueous suspensions (Hedgecock et al., 1995). In addition, oil suspensions improved medium-term storage of $M$. anisopliae conidia (Alves et al., 2002) and enhanced infectivity of conidia (Prior et al., 1988; Bateman et al., 1993). The oil formulation significantly affected phylloplane CFU counts in all Beauveria field experiments conducted. In addition, no visible phytotoxic effects were observed in the sprayed plants. Oil-based formulations of conidia seem to have several advantages over dust formulations for field applications. Formulations of the biocontrol agents with carriers that avoid clumping and favor minimal droplet size may increase wind dispersion of conidia in the crop and consequently, increase the possibility of insect infection or endophytic establishment. However, more extensive studies are needed regarding the physiological interactions of oils at the phylloplane on conidia or hyphal material of entomopathogenic fungi in order to improve their field persistence for pest or disease control.

\section{ACKNOWLEDGEMENTS}

This investigation was financially supported by the Embrapa Soja (Londrina, Brazil) and the Conselho Nacional de Desenvolvimento Científico e Tecnológico CNPq (Brasília, Brazil). The manuscript was approved by Embrapa Soja Editorial Board (number 07/2010).

\section{REFERENCES}

Alves RT, Bateman RP, Gunn J, Prior C, Leather SR (2002) Effect of different formulations on viability and medium term storage of Metarhizium anisopliae conidia. Neotropical Entomology 31:9199.

Alves SB, Pereira RM (1989) Produção do Metarhizium anisopliae (Metsch.) Sorok. e Beauveria bassiana (Bals.) Vuill. em bandejas. Ecossistema 14:188-192.

Bateman RP, Carey M, Moore D, Prior C (1993) The enhanced infectivity of Metarhizium flavoviride in oil formulations to desert locusts at low humidities. Annals of Applied Biology 122:145152.

Chase AR, Osborn LS, Ferguson VM (1986) Selective isolation of the entomopathogenic fungi Beauveria bassiana and Metarhizium anisopliae from an artificial potting medium. Florida Entomologist 69:285-292.

Faria, M, Hajek AE, Wraight SP (2009) Imbibitional damage in conidia of the entomopathogenic fungi Beauveria bassiana, Metarhizium acridum, and Metarhizium anisopliae. Biological Control 51:346-354.

Fehr WR, Caviness CE (1977) Stage of soybean development. Ames. Iowa State University. Iowa Cooperative Extensive Service, Special Report 80. 
Fuxa JR (1984) Dispersion and spread of the entomopathogenic fungus Nomuraea rileyi (Moniliales: Moniliaceae) in a soybean field. Environmental Entomology 13:252-258.

Garcia C, Ignoffo CM (1977) Dislodgement of conidia of Nomuraea rileyi from cadavers of cabbage looper, Trichoplusia ni. Journal of Invertebrate Pathology 30:114-116.

Hajek AE, Elkinton JS, Witcosky JJ (1996) Introduction and spread of the fungal pathogen Entomophaga maimaiga (Zygomycetes: Entomophthorales) along the leading edge of gypsy moth (Lepidoptera: Lymantriidae) spread. Environmental Entomology 25:1235-1247.

Hedgecock S, Moore D, Higgins PM, Prior C (1995) Influence of moisture content on temperature tolerance and storage on Metarhizium flavoviride conidia in an oil formulation. Biocontrol Science and Technology 5:371-377.

Inglis GD, Goettel MS, Johnson DL (1995a) Influence of ultraviolet light protectants on persistence of the entomopathogenic fungus, Beauveria bassiana. Biological Control 5:581-590.

Inglis GD, Johnson DL, Goettel MS (1995b) Effects of simulated rain on the persistence of Beauveria bassiana conidia on leaves of alfalfa and wheat. Biocontrol Science and Technology 5:365-369.

Jandel Scientific (1994) Sigmastat Statistical Software. User's Manual. Jandel Scientific. San Jose, California, USA.

Jaronski ST (2010) Ecological factors in the inundative use of fungal entomopathogens. BioControl 55:159-185.

Johnson DL, Goettel MS (1993) Reduction of grasshopper populations following field application of the fungus Beauveria bassiana. Biocontrol Science and Technology 3:165-175.

Moore D, Bridge PD, Higgins PM, Bateman RP, Prior C (1993) Ultra-violet radiation damage to Metarhizium flavoviride conidia and the protection given by vegetable and mineral oils and chemical sunscreens. Annals of Applied Biology 122:605-616.

Ownley BH, Griffin MR, Klingeman WE, Gwinn KD, Moulton J K, Pereira RM (2008) Beauveria bassiana: endophytic colonization and plant disease control. Journal of Invertebrate Pathology 98:267-70.

Prior C, Jollands P, Le Patourel G (1988) Infectivity of oil and water formulations of Beauveria bassiana (Deuteromycotina: Hyphomycetes) to the cocoa weevil pest Pantorhytes plutus (Coleoptera: Curculionidae). Journal of Invertebrate Pathology 52:66-72.

Rangel DEN, Seth J. Dettenmaier SJ, Fernandes EKK, Roberts DW (2010) Susceptibility of Metarhizium spp. and other entomopathogenic fungi to dodine-based selective media Biocontrol Science and Technology 20:375-389.

Sosa-Gómez DR, Moscardi F (1994) Effect of till and no-till soybean cultivation on dynamics of entomopathogenic fungi in the soil. Florida Entomologist 77:284-287.

Sosa-Gómez DR, Moscardi F (1998) Laboratory and field studies on the infection of stink bugs, Nezara viridula, Piezodorus guildinii and Euschistus heros (Hemiptera: Pentatomidae) with Metarhizium anisopliae and Beauveria bassiana in Brazil. Journal of Invertebrate Pathology 71:115-120.

Sosa-Gómez DR, Delpin KE, Moscardi F, Farias JRB (2001) Natural occurrence of the entomopathogenic fungi Metarhizium, Beauveria and Paecilomyces in soybean under till and no-till cultivation system. Neotropical Entomology 30:407-410.

Southwick EE, Ferro DN (1984) Microclimates of small arthropods: estimating humidity within the leaf boundary layer. Environmental Entomology 13:926-929. 